\title{
Bioactive Proteins and Peptides as Potential Components of Nutraceuticals from Melinjo Seed (Gnetum gnemon)
}

\author{
Tri Agus Siswoyo* \\ Graduate School of Biotechnology and Center for Development of Advanced Science and Technology (CDAST), University of Jember, Indonesia
}

Submission: April 16, 2018; Published: May 14, 2018

"Corresponding author: Tri Agus Siswoyo, Graduate School of Biotechnology and Center for Development of Advanced Science and Technology (CDAST), University of Jember, Jln Kalimantan III/23 Jember 68121, Indonesia, Email: triagus.faperta@unej.ac.id

\section{Abstract}

This mini review deals with main bioactive protein or peptide identified of melinjo (Gnetum gnemon) seed, from biochemical and agromonic aspect. These bioactive protein and peptides could be employed in the food industry as an antioxidant or antihypertension agents to replace synthetic coumpounds and may be used in formulation of functional foods, nutraceuticals, and natural drugs because of their health benefit effects.

\section{Introduction}

These last two decades have presented new groundbreaking field research associated with bioactive food components that not only provides sufficient nourishment, but also found to presents significant health advantages. Food derived bioactive components can be described as substances which may be a source of nourishment but also wield a certain regulative function in the human organism apart from its basic nutrition function. Furthermore, bioactive proteins and peptides obtained from food derivatives assert as health enhancing components which helps to ward off disease or enhance a specific physiological function.

Peptides are similar to proteins in being composed of amino acids but differ in having smaller number of such residues than proteins. In general, the average molecular weight of peptides is $<10 \mathrm{kDa}$ while proteins have sizes bigger than $10 \mathrm{kDa}$ [1] and may exist naturally or may be produced by cleavage from an encryted sequences of native proteins. Releasing peptides from its native protein bond can be carried out by enzymatic protein hydrolysis through digestive, microbial or plant proteolytic enzymes which breakdown the protein resulting in smaller peptides [2]. Exclusively, bioactive peptides for humans were found to have diverse health propertise which among them are antiproliferative, antimicrobial, antihypertensive, antithrombotic, anticholesterole, antioxidant, enhancement of mineral absorption or bioavailability and opioid-like activities [3].
Past studies identified that significant bioactive peptides were found to be derived mostly from everyday food sources which among them are plants and plant produce. Seeds and legumes are among the extensive array of plant produce and are considered a dominant source of nutrition and bioactive peptides [4]. Dicotyledonous seeds which are often misspent, have the potential to become a cost effective alternative towards obtaining plant-based protein supplements. Traditionaly, dicotyledonous seeds are also allready well known for human food sources and livestock consumption. This review will describe the agronomical and biochemical aspects of Gnetum gnemon seed protein-derived bioactive peptides, focusing mainly on the agronomical practices put in place in order to achieve increased concentration of bioactive peptides in plant food.

\section{Protein characters of Gnetum gnemon Seed}

Gnetum gnemon (melinjo), L (Gnataceae) is a mainly found and cultivated in Southeast Asia and Melanesia such as in Indonesia, Malaysia and other islands for its seed, leave and timber [5]. In Indonesia, the seed itself is commonly used as a main ingredient in many traditional indonesian culinary. Gnetum gnemon $L$. seed flour was found to be rich in protein $(19.0 \mathrm{~g} / 100 \mathrm{~g})$, crude fibre $(8.66 \mathrm{~g} / 100 \mathrm{~g})$, carbohydrates $(64.1 \%)$, total dietary fibre (14.5\%) and encompassed adequate amounts of essential amino acids, fatty acids and minerals [6]. From the nutritional viewpoint, all legume and seed storage proteins are relatively low in sulphur-containing amino acids, methionine, 
and cysteine, but the amounts of another essential amino acid, lysine, are much greater than in cereal grains. Two dominant protein was found from G. gnemon seed with molecular weights of approximately $30 \mathrm{kDa}$ (Gg I) and $12 \mathrm{kDa}$ (Gg II) by SDS-PAGE. The N-terminal amino acid sequence of GgII is Gly-Asn-Gly-LysAla-Thr-Val-Ala-Ile-Leu-Val-Lys-Glu-Lys-Val-Glu-Tyr-Gly-Glu-Glu. As expected, the $\mathrm{Gg}$ I failed to be determined probably because its N-terminus was blocked. Similiarly, the N-terminal of some storage proteins from mungbean, oat, cotton, rice, and rape were also reported to be blocked. As confirmation, the peptide mass fingerprinting of two protein was acquired by matrix-assisted laser desorption/ionization time-of-flight mass spectrometry (MALDI TOF-MS). The result showed that they were distinct from each other; no protein in database matching was found to both GgI and GgII [7].

\section{Biochemical effects of Gnetum gnemon protein seeds}

Melinjo seed protein was purified using precipitation method and ion exchange chromatographic techniques to identify the potent antioxidant or free radical-scavenging activities. The antioxidant or free radical-scavenging activities of Gg-AOPs were investigated by employing in vitro assay systems including the inhibition of linoleic acid autoxidation, scavenging effect on $\alpha, \alpha$-diphenyl-beta-picrylhydrazyl free radical (DPPH), 2,2'-azino-bis (3-ethylbenzothiazoline-6-sulfonic acid) (ABTS), reducing power, chelating abilities of metal ions $\mathrm{Cu}^{2+}$ and $\mathrm{Fe}^{2+}$, and protections against hydroxyl radical-mediated DNA damages. The result showed that two protein fractions exhibited significant $(\mathrm{p}<0.05)$ antioxidant activities against free radicals such as DPPH, ABTS, and superoxide anion, and showed similar activities to glutathione and BHT in a linoleic acid emulsion assay system. Moreover, Gg-AOPI and II also exhibited notable reducing power and strong chelating effect on $\mathrm{Fe}^{2+}$ and protected hydroxyl radical-induced oxidative DNA damage [8-10].

Furthermore, Angiotensin Converting Enzyme (ACE) Inhibitory peptide form melinjo seed protein (Gg-SP) was also identified and isolated using sequential chromatographies. Melinjo seed protein hydrolysate was obtained by treatment with different proteases. The hydrolysate generated by peptidase had the highest free radical scavenging activity on ABTS radicals and ACE inhibitory activity and then fractioned and purified using preparative RP-HPLC. The last step result demonstrated that the fraction Gg-SP-A35 exhibited the highest ACE inhibitory and antioxidant activity compared to the other fraction peptides. The molecular mass of Gg-SP-A35 was 801 Dalton determined using a MALDI-TOF MS/MS. The IC50 value of was displayed the highest ACE inhibitory and ABTS radical scavenging activity.

\section{Agronomical aspects}

Plant bioactive peptides perform a large variety of functions, including defense against pathogen infection and regulation of growth and development. In addition, some plant-food peptides play crucialroles for human health maintenance. In order to foster the intake of healthy bioactive peptides, an important strategy is to increase their concentration in plant foods through optimal crop management. It is important to note that, while numerous scientific reports on the identification and characterizationof bioactive plant peptides are available, very few studies on the correlation between agronomical practices and natural peptides concentration have been conducted. Conversely, no data on bioactive peptides derived from protein hydrolysis are available.

Crop management is considered as series of crop cultivation procedures which consider parameters such as soil fertilization, irrigation and pest management [11-14]. Irrigation management includes decisive water usage, controlled irrigation scheduling, drainage and salinity monitoring to improve irrigation efficiency. Recent studies in pest management shows the tendency to favor towards a sustainaible agroecosystem by means of implementing biocontroled pest control. The agronomical practice and the cultivar used in the crop management are also able to influence the accumulation of bioactive peptides of the crops, as have been found in the cereal proteins [15].

Crops are sensitively affected by environmental condition. There are several unfavorable environmental such as high salinity, low water availability, extreme temperature, light intensity, insects and pathogen attacks [16], which caused the changed on the plant metabolism including morphological, biochemical, and molecular mechanism [17]. Plant develop the various defense mechanism to cope with those stresses, once is by increasing the accumulation of various functional proteins [18-20].

\section{References}

1. Farrokhi N, Whitelegge JP, Brusslan JA (2008) Plant Peptides and Peptidomics. Plant Biotechnol J 6(2): 105-134.

2. Belovic MM, Mastilović JS, Torbica AL, Tomić JM, Stanić DR, et al. (2011) Potential of Bioactive Proteins and Peptides for Prevention and Treatment of Mass Non-Communicable Dieseases. Food Feed Res 38(2): 51-61.

3. Bougle A, Bouhallab S (2015) Dietary Bioactive Peptides: Human Studies. Crit Rev Food Sci Nutr 57(2): 335-343.

4. Marambe PWMLHK, Wanasundara JPD (2012) Seed Storage Proteins as Sources of Bioactive Peptides. Bioactive Molecules in Plant Foods 2: 49-50.

5. Manner HI, Elevitch CR (2006) Species Profiles for Pacific Island Agroforestry. Permanent Agriculture Resources 1-6.

6. Bhat R, Yahya NB (2014) Evaluating Belinjau (Gnetum gnemon L.) Seed Flour Quality as a Base for Development of Novel Food Products and Food Formulations. Food Chemistry 156: 42-49.

7. Siswoyo TA, Eka M, Lee KO, Hosokawa K (2011) Isolation and Characterization of Antioxidant Protein Fractions from Melinjo (Gnetum gnemon) Seed. Journal of Agricultural and Food Chemistry 59(10): 5648-5656.

8. Dewi AAIPS, Susilawati IDA, Siswoyo TA (2016) Antioxidant Activity of Hydrolyzed Melinjo (Gnetum gnemon) Seeds Protein Against Neutrophil Superoxide Radical In Vitro. IJASET 4(4): 150-154.

9. Siswoyo TA, Matra NF, Safiera AA, Supriyadi A (2017) Synthetic of Antioxidant Peptides from Melinjo Seed Protein Isolated Using Sol-Gel Immobilized Alcalase. IJASEIT 7(4): 1315-1321. 
10. Siswoyo TA, Ardyati T, Hosok Awa K (2017) Fermentation-Induced Changes in Antioxidant Activities and Oxidative DNA Damage Protection of Melinjo (Gnetum gnemon) Flour. Journal of Food Biochemistry 41(3).

11. Chassy AW, Bui L, Renaud ENC, Horn MV, Mitchell AE (2006) ThreeYear Comparison of the Content of Antioxidant Microconstituents and Several Quality Characteristics in Organic and Conventionally Managed Tomatoes and Bell Peppers. J Agric Food Chem 54(21): 8244-8252.

12. Mitchell AE, Hong YJ, Koh E, Barret DM, Braynt DE, et al. (2007) TenYear Comparison of the Influence of Organic and Conventional Crop Management Practices on the Content of Flavonoids in Tomatoes. J Agric Food Chem 55(15): 6154-6159.

13. Sakadevan K, Nguyen ML (2010) Extent, Impact, and Response to Soil and Water Salinity in Arid and Semiarid Regions. Advances in Agronomy 109: 55-74.

14. Rusch A, Morison MV, Sarthou JP, Estrade JR (2010) Biological Control of Insect Pests in Agroecosystems: Effects of Crop Management, Farming Systems, and Seminatural Habitats at the Landscape Scale: A Review. Advances in Agronomy 109: 219-241.
15. Ortiz-Martinez M, Winkler R, Garcia-Lara S (2014) Preventive and Therapeutic Potential of Peptides from Cereals against. Cancer J Proteomics 111: 165-183.

16. Ghosh D, Jian X (2014) Abiotic Stress Response in Plant Roots: A Proteomics Perspective. Frontiers in Plant Science 5(6): 1-13.

17. Nejat N, Mantri N (2017) Plant Immune System: Crosstalk Between Response to Biotic and Abiotic Stresses the Missing Link in Understanding Plant Defense. Current Issues in Moecular Biology 23: $1-16$.

18. Vaseva I, Yasar A, Lyudmila SS, Anelia K, Rosa N, et al. (2012) Antioxidant Response to Drought in Red and White Clover. Acta Physiology Plant 34(5): 1689-1699.

19. Hirayama T, Shinozaki K (2010) Research on Plant Abiotic Stress Responses in the Post-Genome Era: Past, Present and Future. Plant J 61(6): 1041-1052.

20. Henchion M, Maria H, Anne MM, Mark F, Brijesh T (2017) Review Future Protein Supply and Demand: Strategies and Factor Influencing a Sustainable Equilibrium. Foods 6(7).

\begin{tabular}{l} 
Your next submission with Juniper Publishers \\
will reach you the below assets \\
- Quality Editorial service \\
- Swift Peer Review \\
- Reprints availability \\
- E-prints Service \\
- Manuscript Podcast for convenient understanding \\
- Global attainment for your research \\
- Manuscript accessibility in different formats \\
( Pdf, E-pub, Full Text, Audio) \\
- Unceasing customer service \\
Track the below URL for one-step submission \\
https://juniperpublishers.com/online-submission.php \\
\hline
\end{tabular}

